\title{
Religious Values and Corruption in Nigeria- A Dislocated Relationship
}

\author{
Adenugba, Adetutu Adebimpe (Phd)
}

Dept. of Sociology, University of Ibadan Email: bimpeadenugba@yahoo.com

Omolawal, Samuel Ayodeji. (Phd)

Dept. of Sociology, University of Ibadan Email:omolawal01@yahoo.com

Doi:10.5901/jesr.2014.v4n3p522

\begin{abstract}
Religion permeates the life of every human being as well as every society throughout the world, and every religion has norms, values and acceptable standards contained in its doctrine. By inculcating in adherents these norms and values, religion is expected to promote social control and acceptable standards in the society, thereby reducing vices such as corruption. Thus religion and corruption are seen as having a symbiotic relationship. Focusing on the Christian religion, this paper argues that the prevalence of corruption in the Nigerian society today is an indication that the Christian religion is failing and is losing its potency to correct the vices in the society. It argues further that Christianity has been bastardized and commercialized to the extent that it is losing its appeal as a promoter of right values and spiritual standing as a result of factors such as quest for prosperity/materialism by adherents and religious leaders, quest for power, victory over perceived enemies; selfish interests, sycophancy and the like, all at the expense of the virtues and moral standards emphasized in the Bible. The paper concludes that not only has the Christian religion as an anti-virus failed in its function to cure a virus such as corruption, it has in itself become a citadel of corruption and the paper recommends that governments at all levels, religious leaders, adherents and the entire masses have a big role to play if the fight against corruption in Nigeria is to be successful.
\end{abstract}

Keywords: Religion, Corruption, Christianity, Spiritual values, Society

\section{Introduction}

There is a consensus that corruption is a human problem: It has existed in all ages and in every part of the world. It was said to be partly responsible for the fall of the Roman Empire although historians prefer to refer to it as decadence in that connection. Some Sophists have come up with the theory that corruption has its own redeeming features. They argue that even when a man amasses his wealth by corrupt means, the wealth is bound to flow back to the poor people who need it more in the form of employment opportunities created with the wealth on the assumption that he does not invest it on some selfish projects. In other words, the Sophists will justify the means by the end. Certainly it is left for members of a society to decide for themselves what they want and to say whether they subscribe to the idea that some forms of corruption are justified in some circumstances. Corruption is an indication of absence of human values 9Ehusani, 2003).

World wide, religion does not only prepare adherents for life everlasting after the existence in the physical world, but also to ensure that adherents live a holy and pure life. Hence adherents are expected to imbibe some values and virtues to promote peace within the society. This implies that religion serves as a means of social control. Unfortunately, religion as practised by both religious leaders and followers in Nigeria today, has become commercialized to the extent that anything goes. From theft of church money to ritual killing in the name of money; from deceits by religious leaders to willingness of followers to engage in dastardly acts; from fornication and adultery by leaders to hero worship of criminals, fraudsters, election riggers and sycophants; acquisition of titles and self proclamations such as Bishop, Most Senior Apostle Dr; Founder Prophet Pastor Evangelist Dr and so on. The only thing that is yet to be seen is the outright inclusion of 'limited or PLC' after the name of these churches, yet what they do therein is much more businesslike than the so called limited or public companies. However, the prevalence of corruption in the society is an indication of the failure or failing role of religion to serve as a social control (Yusuf, 2003). It is against this background that this paper is aimed at looking at the role of religion in curbing corruption in the society and to what extent religion and corruption have impacted in the Nigerian society. 


\section{Conceptual Clarification}

\subsection{Religion}

The term religion refers to faith in a divinely created order of the world, agreement with which is the means of salvation for a community and thus for each individual who has a role in that community. In this sense the term applies principally to such systems as Judaism, Christianity, and Islam, which involve faith in a creed, obedience to a moral code set down in sacred Scriptures, and participation in common practices. In its most specific sense the term refers to the way of life of a monastic or religious order (Richardson 1966, Encyclopedia Encarta 2005). For the purposes of this paper, the author is focusing on the Christian religion.

\subsection{Christianity}

Any phenomenon as complex and as vital as Christianity is easier to describe historically than to define logically, but such a description does yield some insights into its continuing elements and essential characteristics. One such element is the centrality of the person of Jesus Christ. That centrality is, in one way or another, a feature of all the historical varieties of Christian belief and practice

The ultimate principle of the universe, called by many different names in various religions, was called "Father" in the sayings of Jesus, and Christians therefore call Jesus himself "Son of God". At the very least, there was in his language and life an intimacy with God and an immediacy of access to God, as well as the promise that, through all that Christ was and did, his followers might share in the life of the Father in heaven and might themselves become children of God. Jesus' crucifixion and Resurrection, to which early Christians referred when they spoke about him as the one who had reconciled humanity to God, made the cross the chief focus of Christian faith and devotion and the principal symbol of the saving love of God the Father.

This love is, in the New Testament and in subsequent Christian doctrine, the most decisive among the attributes of God. Christians teach that God is almighty in dominion over all that is in Heaven and on Earth, righteous in judgment over good and evil, beyond time and space and change; but above all they teach that "God is love" (John 4:16). The creation of the world 'ex nihilo' (out of nothing) and the creation of the human race were expressions of that love, and so was the coming of Christ (John 3:16). The classic statement of this trust in the love of God came in the words of Jesus, in the Sermon on the Mount: "Look at the birds of the air: they neither sow nor reap nor gather into barns, and yet your heavenly Father feeds them. Are you not of more value than they?" (Matthew 6:26). Early Christianity found in such words evidence both of the special standing men and women have as children of such a heavenly Father and of the even more special position occupied by Christ. That special position led the first generations of believers to rank him together with the Father, and eventually "the Holy Spirit, whom the Father [sent] in [Christ's] name". After controversy and reflection, that confession took the form of the doctrine of God as Trinity. The instruction and exhortation of Christian preaching and teaching are based around the two chief commandments encapsulated in the ethical message of Jesus (see Matthew 22:34-40), the love of God and the love of one's neighbor. (Crudence 1975, Encyclopedia Encarta 2005)

\subsection{Corruption}

In a very simple form, corruption means to destroy the purity of something. It is not manifested in fraud or diversion of physical and tangible things alone, it goes beyond this to encompass abuse, rottenness, misuse, decay and depravity (Labanjo 1970). The Act establishing the Independent Corrupt Practices and other related offences Commission (ICPC) defines corruption as including bribery, fraud and other related offences (Corrupt Practices Act 2000). Corruption is defined by the World Bank as 'the abuse of public office for private gains. It involves the seeking or exacting of a promise or receipt of a gift or any other advantage by a public servant in consideration for the performance or omission of an act, in violation of duties required of the office. It may also involve extortion of monies or theft by public servants of amounts due or payable to public coffers' (cited in Onuoha 2003). To Otite, as cited in Onu (2001), corruption is the reversion of integrity or state of affairs through bribery, favour or moral depravity According to Ikeanyibe and Imhanlahimi (2006), corruption is an antithesis to ethics and accountability. They adduced a few reasons for the precarious situation of corruption in Nigeria among which are ineffective institutions, weak rule of law, low popular participation in politics, weak protection of civil liberties, closed economic and political systems, poor remuneration of public servants and so on. However, according to Ighodalo, (2001), while these factors can not be overlooked, moral leadership and true 
commitment to the service of the nation are at the centre of the situation.

\section{Christian Religious Values and Corruption in Nigeria- A Dislocated Relationship}

According to Henslin (2007), religion serves the following fucntions:

- Provides answers to perplexing questions about ultimate meaning such as the purpose of life, why people suffer, existence of after life. Etc.

- Provides emotional comfort especially during the time of illness, death, suffering and so on.

- Provides social solidarity- unites believers into a community that shares same positive values.

- Provides guidelines for every day life through rules and regulations on what to do and what to abstain from.

- Provides social control so that fairness and justice will be displayed.

- Provides support for the government.

In Nigeria, Religion features at the beginning of the nation's constitution. Chapter 1, Part II (10) prohibits the adoption of any religion as state religion and Chapter IV (38) gives freedom to all citizens on the religion to practise and that no religion should be forced on any citizen against his will. The question then is, what is the situation on ground in Nigeria?

As a matter of fact, most Nigerians are religious. They believe in the supremacy of God and that God is the basis of their individual and corporate lives. As ministers and followers of Christ, the Bible spells out numerous requirements as foundations for their faith. Most important, Romans 12:2 says 'do not be conformed to this world, but be transformed by the renewal of your mind, that you may prove what is the will of God, what is good and acceptable and perfect.' Matthew 6: 33 adds that' but seek first the kingdom of God and its righteousness, and all these things shall be yours as well. Luke 9:23 says " if any man would come after me, let him deny himself and take up his cross daily and follow me.' Again, the Bible in Matthew 5: 13 \& 14 refers to Christians as salt and light of the world, indicating that they occupy special place in the scheme of events and to be examples for the world to emulate. The question is, what manner of Christianity do Nigerians (Leaders and followers) practise?

Nigerians relate with supernatural realities through prayers, supplications, fasting and offering of sacrifices. Ever since the spread of the gospel to the country, Nigerians have embraced and adopted and practised it with fervour and passion. In the recent past, the spirit of 'born againism' has taken over. Churches are found in all nooks and crannies of the streets. There are churches in the forests, riversides, on hilltops and mountains. Crusades are organized daily. Worship sessions and vigils take place every minute of every day of the week. People go in large numbers on pilgrimage taking pride in being addressed as Alhajis or JPs. According to Ehusani (2003), while there is noticeable decline in religious fervor in many parts of the world, the religious enterprise appears to be thriving very much in Nigeria, as more people are being converted, many houses and house wares are being turned to churches, sports stadia are being used more for religious functions than for sporting activities. Streets and highways are blocked at regular interval for religious meetings and crusades. To Yusuf (2003), unfortunately in most of these churches, holiness seems to be unpopular, as the vows of celibacy and life devoid of glitters has been overtaken and replaced by Pastors with flamboyant lifestyles, beautifully groomed hair, expensive clothes and shoes, posh homes and cars and even private jets. These clerics tell their congregation that their God is not a poor God, a cliché that has earned them the name 'prosperity preachers'. Some have gone a step further to seek and acquire fetish power so as to be able to tell their followers certain secrets and to make predictions for them. Some are believed to use 'anointed' handkerchiefs, anointed rings, holy water etc' to cure sicknesses and diseases. Most topics of crusades are coined in catching phrases such as 'your miracle is today, overcoming the devil, victory at last, march into your wealth, claim your fortunes today etc'. These phrases serve their desired purpose of attracting followers. The largest bill boards on the streets are those advertising one religious crusades/faith healing or the other. Religious phrases such as praise God, Halleluiah, Jesus is Lord and so on are commonly on the lips of people any where and anytime of the day. Some establish their churches and make themselves the General overseer, their wives Deputy General Overseer or Treasurer, their son the Secretary and so on. It is common knowledge that most of these pastors now go about with armed body guards, bouncers and other official paraphernalia such as secretaries, personal assistants, protocol officers and others.

What more? Seminaries, Monasteries, Bible Colleges are increasing and they are turning out thousands of preachers, evangelists and prophets. The missionaries are so numerous to the extent that they are now sent out to various missions in Europe, America, Asia and other countries of the world. Some of these churches have even become venues for corrupt politicians (who come with all the paraphernalia of office) to campaign and to give thanks to God after 'winning' elections which were believed to have been rigged. They are at times given the microphone to address the 
congregation and give account of their stewardship.

Thus from all indications and outward manifestations, Nigerians seem to be incurably religious and perhaps the most religious in the world. But in the face of this fervor and religiousity, should order, peace, love, selflessness, charity, humanity to man, and other fruits of the spirit listed in (Galatians 5:22-23) not be clearly visible and manifested in Nigeria? Put in another way, should there be corruption, rancor, poverty, inhumanity, poor governance and so on in the land?

Having briefly reviewed the situation on ground in Nigeria, is the Christian religion serving the desired purpose of increasing moral and spiritual values?

The situation on ground in Nigeria does not appear to show that the Christian religion is serving these functions. For example, social solidarity is low as believers are no longer united into a community that shares Christian values, thus what the Anglican does differs from what the Catholic does, and the individuality becomes more pronounced among the Pentecostal/independent churches where values are defined by the leaders and not by the Bible. Fairness and justice are scarce commodities especially when politicians and rich people are accorded more recognition and attention than the poor in the same church and where virtues of criminals and fraudsters are extolled openly and so on. Religion is unfortunately providing a negative support for government as most government officials use it to abuse the collective conscience of the people through their deceits and manipulation. From all indications, it could be seen that long before the global economic meltdown currently being experienced, Nigeria has been experiencing religious meltdown and not only has it failed to curb corruption, but it has in itself become a channel of corruption.

A review of the current situation will prove that there is religious meltdown in Nigeria: One does not have to labour so hard to establish the fact that there is so much corruption going on in Nigeria. Pages of national newspapers reveal on daily basis one form of corruption perpetrated especially by public servants who are placed in positions of authority to provide good governance for the masses. Corruption is near endemic as well as systemic in Nigeria. There are manifestations of negative practices involving private individuals, public officials, political office holders at all levels, students, market men and women and in short almost every body. Corruption has succeeded in breeding inefficiency in Nigeria, is diminishing productivity in all sectors, it is discouraging investment, fuelling capital flight, increasing unemployment and inflation, creating and promoting poverty, bringing decline in quality of life and life expectancy and giving Nigeria a bad image in the eyes of the international community. In all it is a negation of the Christian vocation to promote holiness and righteousness in the world. The situation can be likened to what happened in Sodom and Gomorrah where God could not find ten honest people that will warrant saving the towns from destruction. Realizing this situation, successive Heads of States and Presidents have had to decry the alarming rate at which corruption is flourishing in Nigeria, and this was what informed the immediate past government to establish the Independent Corrupt Practices and Other related Offences Commission (ICPC) and the Economic and Financial Crime Commission (EFCC) to mount wars against corruption. Other agencies include Extractive Industries Transparency Initiative (EITI), Code of Conduct Bureau, Due Process Unit in the Presidency and so on. The success of these and other agencies is subject to further debates. What factors then encourage corruption in this country?

Foremost, Adeleke (2003) claims that Nigerian leaders over the last 40 years have created an environment that is conducive for corrupt practices while a disoriented and impoverished followership, and anybody else operating in this environment, quickly learns to tow the line and take full advantage. The system has been molded by a society where anything goes. The system has taken on a life of its own, feeding off itself. Society in turn is now a victim of that system. Almost all past leaders have one religious title or the other indicating that they believe in the supremacy of God, a fact which they could bear to bring to their administration. In support of this, Onuoha (2003) says 'the ruling class is parasitic, exploitative, unproductive and devoid of the tempers of nationalism and state building; in turn, the state lacks autonomy and is subordinated to dominant class interest; the implication is that both the state and the dominant and ruling class work for their own interests and not for the interests of the whole society'. A case for consideration is the issue of immunity clause which agents of the state created for themselves in anticipation of their abuse of office. This provides an opportunity for them to be corrupt and to cover their trails and destroy evidence while still in office. It does not seem to be a matter of contradiction for many highly placed Nigerians that they embezzle or misappropriate millions of naira while at the same time struggling to occupy front seats in the church or even take titles in the church. Many of these leaders during the oath taking ceremonies swear to the Bible to provide faithful and honest governance and protect the integrity of the nation and such declaration ends at the point of the ceremony as actions immediately thereafter reek of corruption and dishonesty. A careful assessment of all the sectors of the Nigerian economy under different administrations over the years will reveal cans of worms and the extent to which past and present leaders have corrupted themselves and succeeded in creating avenues for corruption. This conclusion is amply supported by Nduka (2006), who says that 
'apparently, there have been deficits in the national leadership either from the intellectual, moral, ideological or other points of view. He continues, 'in my view, the weakest link in the chain of developmental efforts remains the weak value base which adversely affects both our individual and collective attempts at development, including those of the leaders who are either born, selected, rigged into positions of leadership or assume the leadership of the country through the barrel of the gun'. It is no secret that most of Nigerian leaders in the past either came in through the barrel of the gun or through election rigging. That automatically puts a question mark on their level of spiritual/religious and moral standing. They have not helped the situation with the kind of leadership they have subsequently displayed. Privileges to occupy public and political offices do not imply opportunities to display personal aggrandizements, whims and caprices. Office holders must offer honest leadership for others to follow; they must exhibit a sense of fairness and equity and must show a sense of honour that involves integrity and internal moral control.

Transparency and accountability, which are marks of good leadership, are missing from their dictionary. Selfishness, ethnicity, tribalism, nepotism, greed are marks of their regimes. Poor governance leading to a culture of poverty further provides avenues for people to make ends meet at all cost. These marks provide well fertilized ground for corruption to thrive and boom as is currently the case today. As a way out of the crisis of corruption, the government of Nigeria has established bodies like the ICPC and EFCC to fight corruption, but unfortunately the bodies were crippled right from birth by the legal documents that established them and this has been further worsened by the absence of political will on the part of the government to fight corruption (Onuoha 2003).

Apart from the government, society itself has further encouraged corruption through excessive hero worship bordering on mass sycophancy. This manifests in the attitude of 'my leader, right or wrong'; 'my town, by hook or crook'; 'my tribe, right or wrong'. It is the root of such ethnic and tribal sentiments that many people use to foster corruption. Akin to sycophancy is hero worship even when we know such heroes have committed atrocities. Once they come around and throw a few material things around or when they dash out money to traditional rulers, they easily become heroes to be worshipped and at times given chieftaincy titles as a mark of their recognition. A culture of ostentation has also emerged thus making it a big disaster for an individual to be poor. The implication here is that people would do or be ready to do anything at all cost to acquire money even if it will mean emptying the public treasure to do that.

Do Nigerians who worship God as followers or leaders not know what Isaiah 33:15 say ' those who are honest and fair, who refuse to profit by fraud, who stay far away from bribes, who refuse to listen to those who plot murder, who shut their eyes to all enticements to do wrong; he shall dwell on high...' Luke 3:13-14 warns against fraud, extortion, intimidation and the need to be contented with one's pay. Jesus himself preached against religious practice that was not matched by high moral and ethical standards in private and social life (Sermon on the Mount-Matthew 5).

In the face of the contradiction and the embarrassment of a booming Christianity in the midst of an environment that stinks with corruption and indiscipline, the conclusion seems to be that what is spreading like wild fire in contemporary Nigeria is not genuine Christianity at all, but a mass movement of some sort with Christian elements of ritualism; one that is largely shallow, superficial, noisy and devoid of substance and depth. Popular Christianity in Nigeria appears to be largely materialistic, unspiritual and with emphasis on prosperity, success, healing and with little attention on social morality and spirituality of the believers. This brand of Christianity does not seem to have a place for the notion of the cross, suffering and sacrifice which constitute the centre of traditional Christian doctrine and life. At a time when Christian leaders should use the message of the cross and a modest and austere life to contradict the gross materialism and extreme economic liberalism of the current society that are daily crushing the poor, what we see are expensive churches harbouring stinkingly rich pastors whose mark of success are mansions, flashy cars, expensive dresses, shoes, wristwatches, jewelries the costs of which can feed thousands of hungry followers.

Religion has failed in its responsibility to mould the character of the adherents. Religion itself has been thoroughly exploited and manipulated in Nigeria by "smart" men for political and economic gains. The message of the cross is fundamental and central to the Christian religion, but popular religion in Nigeria has sidelined the cross and all the spiritual values associated with it. This religion declares all failure, suffering and pain as of the devil while associating with God only wealth, success, healing and prosperity. Put in computer terminologies, religion could be seen as an antivirus such as Avast, MacAfee, AVG and so on. As an anti-virus, the main role is to remove, delete or heal viruses. On the other hand, corruption should be seen as a virus: A virus that has eaten deep into the fabrics of the national conscience and which has deadened all values and morality. Unfortunately, in Nigeria religion has lost its potency to fight the virus of corruption and not just this, corruption has succeeded in infesting and taking over the brain box of religion.

According to Labanjo (1970), we are not asking for a country where all the citizens are saints, but it would not be any use either if all the citizens are sinners. The generally accepted fact is that in every society the saints should redeem the sinners otherwise there would be chaos. The manifestation of chaos in Nigeria could therefore be an indication that 
saints could be scarce to come by, a situation similar to what happened in Sodom and Gomorrah where God was not able to find ten righteous men who could have been used as a basis to save the cities from destruction that eventually came on them.

\section{Conclusion and Recommendations}

From the issues raised in this paper, it could be seen that there is a serious imbalance between the Christian religion and corruption in Nigeria. A dislocation has occurred in the symbiotic relationship between the Christian religion and corruption. Where the level of spirituality is high, all things being equal, the level of corruption should decline. The situation in Nigeria is such that not only has religion failed to reduce corruption, but religion it self has become a channel of corruption, providing support for corruption in the society. What camouflages as popular Christianity in Nigeria and spreading like wild fire and winning thousands of souls may not really be Christianity at all, to the extent that it has thrived in the midst of corruption and social decay and has not been able to make a difference in the social morality and piety of the adherents. In fulfillment of Jesus' declaration, these religious leaders and followers are being known through their fruits. If what is seen exhibited by millions of converts are indiscipline and corruption, then it could be said with little or no fear of contradiction that what is being witnessed in Nigeria are mass movements of some sort, preaching messages of convenience, with a few elements such as singing, prayer and so on. These social movements largely lack the understanding of the Christian call to a high level of sacrifice, discipline, honesty, truth and justice. There is no doubt that authentic religion will checkmate corruption because individual and social morality of the people is predicated on their religious beliefs and values. True religion shares in common transcendental values and moral principles, and also promotes high ethical standards. A proper dissemination of the Christian message will help to checkmate the human instinct to grab and to accumulate for self while neglecting the common good.

Government, religious leaders and the entire citizens have roles to play if Nigeria is to be transformed from the high position in the gang of the most corrupt nations in the world, to a high position among the most corruption free nations.

1. On the part of the government, those in power must fear God and practise their religious obligations and national duties sincerely. This will earn them moral support from the followers. Also there must be a vibrant national view centered on the fear of God, after all, swearing with the Bible or Koran is an indication of weaving individual and national conscience around religion; consequently performance of duties must be seen as an opportunity to serve the nation and put national interests over and above individual interests.

2. Religious leaders also need to wake up from their slumber and take the message of the cross more seriously. They should not see religion as a means of amassing wealth neither should they spare the corrupt individuals and government officials in the course of preaching sermons. They should see their call as a means of inculcating the fear of God and the values of honesty, hard work, accountability and concern for the common good in their members.

3. Finally, individuals and adherents must be ready to face the challenges of life and play down complete dependence on miracles and healings. They must also pay attention to the provisions of the criminal codes against the various shades of corruption and most importantly, they must have the fear of God in their hearts and imbibe this in their children.

\section{References}

Adeleke, John, 2003, Corruption in the Private Sector: How Bad? What Response, in Corruption, Accountability and Transparency for Sustainable Development, Ota: ALF Publications.

Alexander Cruden, A.M., 1975, Crudence Bible Concordance, Michigan: Zondervan Pub.

Bolaji, Labanjo, 1970, Anatomy of Corruption in Nigeria, Ibadan: Daystar Press. Constitution of the Federal Republic of Nigeria, 1999

Ehusani, George, 2003, Religion and the Scourge of Corruption in Nigeria, in Corruption, Accountability and Transparency for Sustainable Development, Ota: ALF Publications.

Encyclopedia Encarta 2005

Henslin, James. M., 2007, Sociology- A Down-to-Earth Approach, $8^{\text {th }}$ Ed., Boston: Allyn \& Bacon Pub.

Ighodalo, A, 2001, Bureaucratic Corruption in Nigeria, In I.Olojede and S.O Fajonyomi (eds), Ethics and Public Accountability in Nigeria, Lagos: A-Triad Associates.

Ikeanyibe, O.M., \& Imhanlahimi, J.E., 2006, Ethics, Accountability and Public Service

Delivery in Nigeria, In Ibadan Journal of the Social Sciences, Vol. 4/No.2, Sept 2006.

Nduka, Otonti. (2006), The Roots of African Underdevelopment and Other Essays, 
Ibadan: Spectrum Books Ltd.

Onu, G, 2001, Corruption and Sustainable Development; The Third World Perspective, Onitsha,

Book Point Limited.

Onuoha, Browne, 2003, Administrative capacity in enforcing sanctions and recommendations

against corrupt practices, in Corruption, Accountability and Transparency for Sustainable Development, Ota: ALF Publications.

Richardson, A., 1966, Religion in Contemporary Debate, London: SCM Press Ltd.

The Corrupt Practices and other Related Offences Act 2000 The Holy Bible

Yusuf, Bilkisu, 2003, Corruption and religious Institutions: the Score board, in Corruption, Accountability and Transparency for Sustainable Development, Ota: ALF Publications. 